\title{
Experimental urinary bladder reconstruc- tion using allogeneic tissue engineering products
}

\author{
Nadezhda V. Orlova ${ }^{1}$, Alexander N. Muraviov ${ }^{1,4}$, Tatjana I. Vinogradova ${ }^{1}$, Natalija M. Yudintceva ${ }^{2}$, Yulia A. Nashchekina ${ }^{2}$, \\ Natalija V. Zabolotnih ${ }^{1}$, Alexander A. Lebedev ${ }^{1}$, Magomedsadik G. Sheykhov ${ }^{1}$, Piotr K. Yablonsky ${ }^{1,3}$ \\ ${ }^{1}$ St. Petersburg State Research Institute of Phthisiopulmonology, St. Petersburg, Russia \\ ${ }^{2}$ Institute of Cytology, Russian Academy of Sciences, St. Petersburg, Russia \\ ${ }^{3}$ St. Petersburg State University, St. Petersburg, Russia \\ ${ }^{4}$ Private University «St. Petersburg Medico-Social Institute», St. Petersburg, Russia
}

Dr. Orlova Nadezhda Valerjevna, Clinical Urologist,

St. Petersburg State Research Institute of Phthisiopulmonology, 191036, Ligovskij Ave, St .Petersburg, Russia
Phone: +7 (953) 3470085

E-mail: nadinbat@gmail.com

Citation: Orlova NV, Muraviov AN, Vinogradova TI et al. Experimental urinary bladder reconstruction using allogeneic tissue engineering products. Cell Ther Transplant 2019; 8(2): 68-73.

\section{Summary}

The article describes the results of an experimental study of tissue-engineering constructions based on lactic acid - poly-L, L-lactide matrix, containing allogeneic cells of various tissue origin.

\section{Aim}

Experimental investigation of the possibility of using an allogenic tissue-engineering graft to replace a defect in the bladder wall.

\section{Materials and methods}

The study was performed on 15 male Chinchilla rabbits. After partial resection of the bladder augmentation cystoplasty was performed with scaffolds containing smooth myocytes with urothelium, fibroblasts and mesenchymal stem cells.

\section{Results}

In $100 \%$ of cases of partial bladder replacement with a cell-free matrix or scaffolds containing smooth myocytes with urothelium and fibroblasts, an implant was rejected with a different severity of the inflammatory reaction and a decrease in the capacity of the bladder.
In the $4^{\text {th }}$ group (mesenchymal stem cells), on the contrary, in 5 cases out of 6 lysis of the matrix occurred, the capacity of the bladders 2.5 months post-surgery was comparable to the preoperative one. At the implantation site, an area of the modified mucous membrane with signs of vascularization was determined. Histologically, the initial stages of reparation and angiogenesis were revealed. With confocal microscopy of cryosections at the implantation site, labeled cells are identified that are involved in the formation of a structure similar to the urothelium.

\section{Conclusion}

The efficiency of using mesenchymal stem cells as part of a tissue-engineered product for partial replacement of the bladder wall was shown. Development of methods of creating multi-component graft using allogeneic cells may improve the results of treatment of pathologies in which no autologous material is available.

\section{Keywords}

Allogeneic transplantation, bone marrow mesenchymal stromal cells, bladder, tissue engineering. 


\section{Introduction}

Tissue engineering occupies the significant position among modern scientific trends. Even so, urological aspects hardly take a prominent place in the total volume of topical publications. In addition, many problems associated with the urinary bladder (UB) reconstruction remain unresolved [1]. For more than 100 years, worldwide scientists have been trying to find tissue analogues of UB wall [2]. Most of these attempts were unsuccessful due to structural and functional problems, as well as biocompatibility failure. For example, a non-resorbable synthetic reservoirs turned out to be mechanically untenable, in addition to stone formation. The use of absorbable materials led to fibroblast infiltration, cicatrization, and, as a result, a decrease in the UB capacity. Currently, when conservative methods fail, urinary tract is reconstructed using fragments of the gastrointestinal tract [3]. Such surgery always leads to various complications [4]. However, despite the high invasiveness of such intervention, they remain the golden standard in these conditions [5]. Hence, search for alternative materials able to replace the UB wall continues unabated. The tissue engineering and regenerative medicine methods can improve the treatment results of many pathological conditions in urology.

Different bioresorbable synthetic polymeric materials are widely used for the treatment of damaged organs and tissues as scaffolds for cell cultivation $[1,6]$. Such scaffolds should have a number of features, such as mechanical strength and non-toxicity (including the harmlessness of their degradation products) [7]. In addition, they should promote cell growth, while the rates of the material biodegradation and recovery of damaged tissue should be comparable [8].

In 1990, Anthony Atala and his group had successfuly replaced the whole UB with an in vitro-grown neo-cyst in a series performed in 14 dogs [9], and then transplanted a similar tissue-engineered construct in human patients [10]. However, only autologous UB tissues were used here as a source of cells. This method is impossible in patients with affected urothelium and muscular wall. Such damaging conditions may be caused by a variety of diseases of the genitourinary system, often including tuberculosis $[11,12]$. Moreover, in case of tuberculosis (as with a number of other infectious diseases) it is not possible to use autologous cells, because a potential hematogenic transfer of the infection cannot be excluded. Allogeneic cell transplantation could be a promising option for such patients using a lactic acid - poly-L, L-lactide, a synthetic scaffold able to serve a matrix for cell proliferation [13].

It is known that some cells of the body do not possess pronounced immunogenicity, and mesenchymal stem cells (MSCs) are even able to modulate the immune response. However, questions about the possibility of using allogeneic cells have not yet been fully investigated [14]. Many issues need to be resolved at the stage of preclinical studies. First of all, it is necessary to find the most suitable cell sources for regeneration of the bladder, to develop suitable matrices and to learn how to work with them.
The aim of present study was to perform experimental investigation of the opportunity of using an allogeneic tissue-engineering graft to replace a defect in the bladder wall.

\section{Materials and methods}

Fifteen adult Chinchilla rabbits were used for studying the results of surgical implantation into urinary bladder. The matrix for experimental implants was composed of polymer material based on lactic acid - poly-L,L-lactide, reinforced with silk fibroin at a 1:1 ratio. During preliminary series of in vivo experiments with different types of scaffolds, this composite did not exhibit toxic properties when implanted under the skin of rats for up to 3 months. Allogeneic cells of various tissue origin were isolated and cultured according to standard techniques, then being introduced in collagen gel into the prepared matrices. Three matrices of group 1 were seeded with allogeneic smooth muscle cells (SMC) and urothelium (U), three of them, with allogeneic skin fibroblasts (FB, group 2), three matrices were left cell-free (group 3 ) and six matrices were seeded with allogeneic MSCs of rabbit bone marrow labeled with superparamagnetic iron oxide nanoparticles (SPIONs) (group 4). The prepared multicomponent composites were implanted after partial UB resection in 15 male Chinchilla rabbits. Under intravenous anesthesia (ketamine 10-50 $\mathrm{mg} / \mathrm{kg}$ and xylazine $1-3 \mathrm{mg} / \mathrm{kg}$ mixture) the bladder wall was dissected and a resection of a fragment $10 \times 10 \mathrm{~mm}^{2}$ was performed. The tissue-engineered graft was placed on the formed defect and fixed with 6.0 Vicryl stitches and then covered with a perivisceral fat. For urine outflow we installed an urethral catheter. The results were evaluated after 2.5 months observation. This time period was chosen after a series of preliminary experiment in rats, which showed resorption of this matrix implanted under the rat skin in 6-8 weeks after the experiment.

All the studies were carried out in accordance with ethical principles of laboratory animals curation "European Convention for the Protection of Vertebral Animals Used for Experimental and Other Scientific Purposes. CETS No. 123" and the Rules of Laboratory Practice (Order of the Ministry of Health and Social Development of the Russian Federation, August 23, 2010 No708n "On Approval of the Rules of Laboratory Practice").

\section{Results}

During the observation period no pathological changes in the blood and urine tests were recorded, also an adequate body weight increase was noted.

At the term of 2.5 months post-surgery, the groups 1, 2, and 3 demonstrated a decrease in bladder capacity of different severity grade, mostly manifested after implantation of FB-containing scaffolds ( $8 \%$ of the original values). A quantitative comparison of rabbit UB capacities at the initiation of the study and at the time of removal from the experiment is presented in Fig. 1. The diagram shows that in groups 1, 2 and 3 there is a varying degree of a decrease in the capacity of the bladder $(8-48.7 \%$ of the preoperative levels, $\mathrm{p}<0.05)$. In group 4 animals, opposite, the capacity of the bladders practically did not change ( $92.6 \%$ of the pre-operative). 


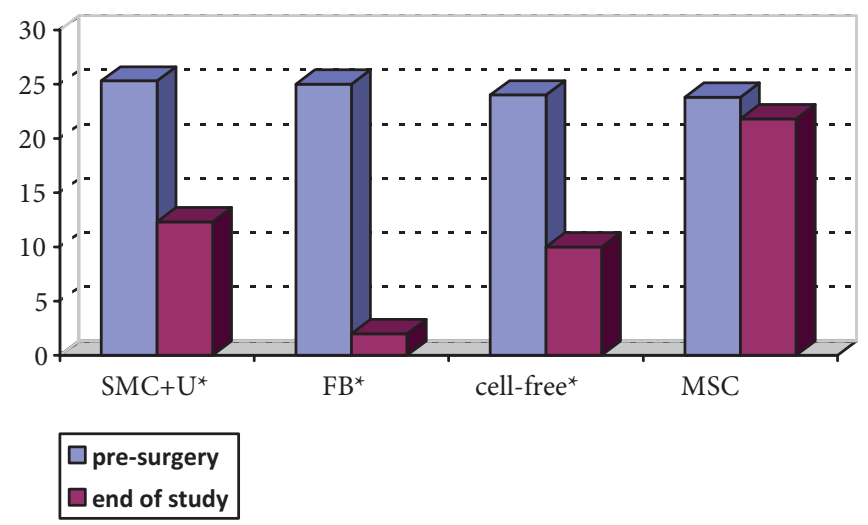

Figure 1. The capacity of rabbit urinary bladders before surgery and at the time of removal from the experiment $(\mathrm{mL})$

Abscisse, types of matrices used: $\mathrm{SMC}+\mathrm{U}$, smooth muscle cells+ urothelium; FB, fibroblasts; MSC, mesenchymal stem cells. Ordinate, urinary bladder capacity, $\mathrm{mL}$.

Note: ${ }^{*}$, the difference of parameters at the beginning and end of the experiment is reliable, $p<0.05$.

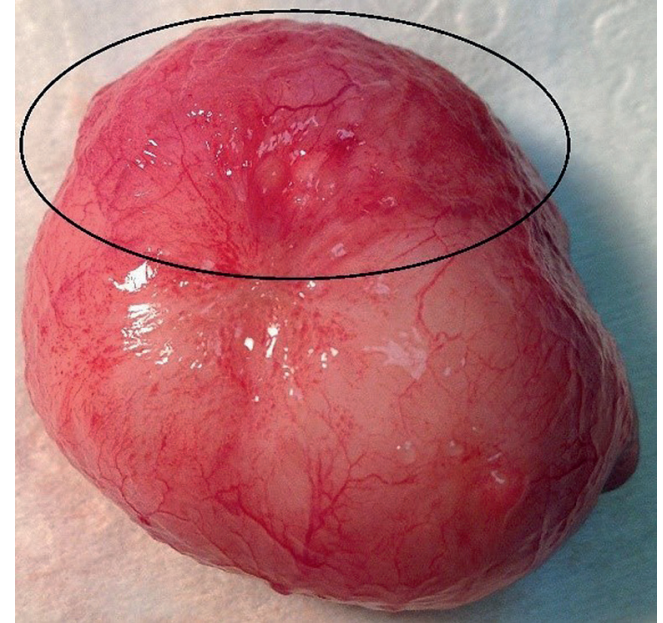

Figure 2. Macroscopic view of implantation site upon necropsy in group 4 (MSC-containing scaffold). The newly formed mucosal area is surrounded by an oval

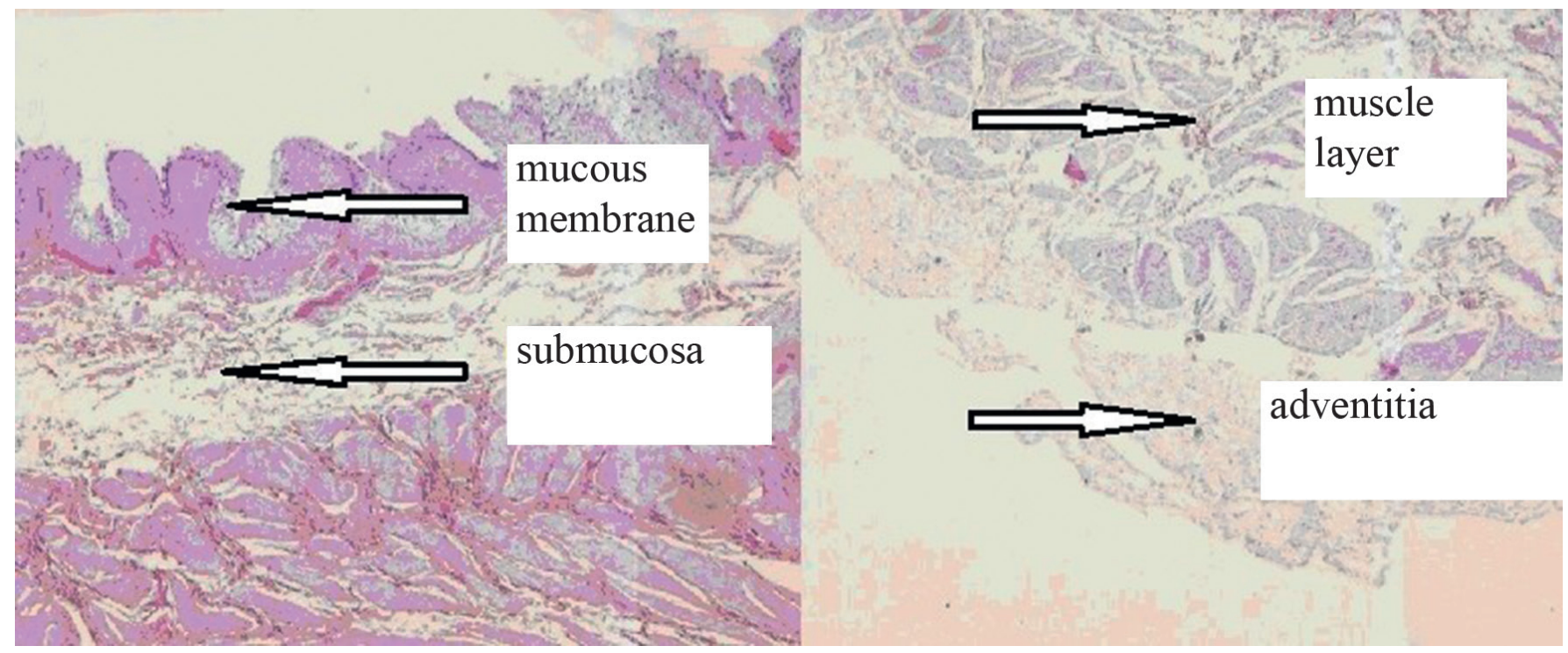

Figure 3. Bladder wall of a rabbit from group 4 (MSC-containing implants) at two months post-surgery. Hematoxylin-Eosin staining. 100x magnification. Newly formed layers (mucous membrane, submucosa, muscle layer and adventitia) are indicated by arrows

During macroscopic examination, no pathological changes of internal organs (except of UB) were identified in either of 15 animals: the parenchymal organs were not visually changed, there was no pathological effusion in the abdominal cavity, intra-abdominal lymph nodes were not visually enlarged. The urinary bladders of animals are investigated macro- and microscopically. Surgical implantation of structures containing allogeneic SMC and urothelium in the $1^{\text {st }}$ group caused a pronounced inflammatory reaction with a decrease in bladder capacity, development of a retracted scar at the implantation site, and displacement of the graft into the surrounding fatty tissue, its encapsulation and necrosis. In the animals from $2^{\text {nd }}$ group (FB), a marked inflammatory reaction was observed, with a significant decrease in capacity and compliance of the bladder. In one animal, it resulted into formation of hydronephrosis. In all cases, the matrix is found in the lumen of the UB, roughly cohesive with the surrounding tissues. In the $3^{\text {rd }}$ group (cell-free implant), the matrix covered with calculi was also found in the lumen of the UB. Like as in the $1^{\text {st }}$ group, a retracted scar with papillary outgrowths of the mucous membrane was formed at the implantation site. The capacity of UB was significantly reduced in all cases. Outside the zone of implantation, the bladder walls were thickened, rigid, and there was a marked adhesion process around the UB.

In the $4^{\text {th }}$ group (MSC-containing scaffold), the picture was strikingly different. 2.5 months post-surgery, the bladder capacity was comparable to the pre-operative one, the UB wall outside the implantation zone were not visually altered. 
At the implantation site, an area of new-formed mucosa with signs of vascularization was determined (Fig. 2).

In 5 of 6 cases (83\%) of MSC-containing scaffold implants, a complete lysis of the matrix was also observed. Only in 1 case, the scaffold displacement into the UB lumen with the calculus formation did occur. On the contrary, in $100 \%$ of cases when using other scaffolds $(\mathrm{SMC}+\mathrm{U}, \mathrm{FB}$, cell-free matrix), the matrix was displaced into the fatty tissue (with encapsulation and necrosis), or into the lumen of the UB with calculus formation.

Histologically, the initial stages of reparation and angiogenesis were revealed in the $4^{\text {th }}$ group (Fig. 3).

The mucous membrane (group 4) along its longitude was represented by transitional epithelium and the lamina propria with a high content of collagen fibers. The thickness of the transitional epithelium was not significantly changed and comprised $88.3 \pm 5.3 \mu \mathrm{m}$. Thickness of the mucosal layer was significantly increased $(62.5 \pm 5.1 \mu \mathrm{m}, \mathrm{p}<0.05)$ as compared with intact rabbits $(22.5 \pm 1.1)$. The submucous membrane was moderately swollen, its thickness compared with the control was significantly increased (to $416.7 \pm 11.8 \mu \mathrm{m}$, $\mathrm{p}<0.05)$. The number of blood vessels per $1 \mathrm{~mm}^{2}$ was comparable to the control $(4.0 \pm 0.0 \mu \mathrm{m})$. The lumen diameter of the vessels remained significantly increased $(85.0 \pm 3.5 \mu \mathrm{m})$. The muscle membrane was also swollen, its thickness was significantly increased to $1583.3 \pm 31.3$ microns, and its content of collagen fibers was increased as well. The thickness of adventitia layer with high contents of connective tissue was $83.8 \pm 8.1 \mu \mathrm{m}$.

The cryosections of the implantation sites were examined by confocal microscopy. Iron-containing nanoparticles were identified, and it was clear that labelled cells participated in formation of a structure similar to urotelium (Fig. 4).

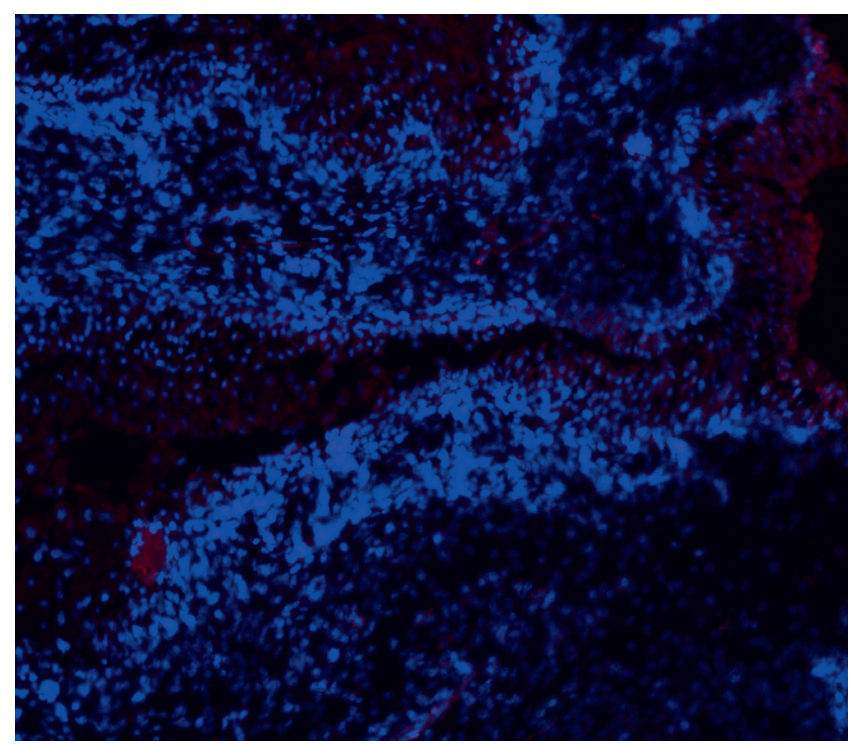

Figure 4. Confocal microscopy of cryosections from Group 4. The implantation site, $x 40$. Cell nuclei were stained with 4',6-diamidino-2-phenylindole (blue) and detected using a diode laser $(\lambda=405 \mathrm{~nm})$. Magnetic nanoparticles (SPION) were detected by reflected laser scanning at $488 \mathrm{~nm}$ (red). Scale bar, $100 \mu \mathrm{m}$.

\section{Discussion}

Impact of allogeneic MSCs on the immune response is of great scientific interest nowadays. In the present experiments, implantation of MSC-containing scaffold caused no significant inflammatory reaction, and also no signs of implant rejection were observed. Perhaps this is due to the MSCs unique feachures, since all implanted cell-free structures as well as matrices with allogeneic FB, SMC and urothelium induced active inflammatory reaction, that persisted even after 2,5 months of experiment. Moreover, the process spread to the surrounding tissues, which was not observed in case with MSC.

In recent years, the results of systemic treatment of MSCs for various diseases [15-17] and experimental work on the reconstruction of various urological structures including UB [18] have been published. World experience in the use of allogeneic MSCs for the UB reconstruction to date is represented by only four experimental studies [13, 18-20].

In conclusion, the current study has proved the opportunity of using a multi-component composite containing allogeneic mesenchymal stem cells for bladder defect replacement, whereas the implants without cell filling and those populated with allogeneic fibroblasts, smooth myocytes and urotelium are inevitably rejected. The technologies of creating a multicomponent graft using allogeneic cells should be further developed, because it can improve the results of treatment of such pathologies in which it is not possible to obtain autologous material. In addition, we are considering a bank of donor material as a promising idea for future pre-clinical and clinical implications. It will greatly simplify and speed up the process of obtaining the neo-organ by the recipient. We also plan long-term experiments, including the replacement of the whole bladder with a spherical reservoir. It is also planned to perform a morphological identification of cells containing SPION labels in the long-term period.

\section{Competing interests}

No conflicts of interest, financial or otherwise are declared by the authors.

\section{Acknowledgement}

This study was supported by a grant from the Russian Science Foundation (No 14-50-00068) and with financial support from the Federal Agency of Scientific Organizations (Russia).

The authors are grateful to Marina Parr, Liudmila Yakovleva, Yaroslav Marchenko, and Boris Nikolaev for synthesis of the magnetic nanoparticles, Igor Samusenko for hystologic examimation and Yuliya Idrisova for analysis of scaffold properties.

\section{References}

1. Muravjev AN, Orlova NV, Blinova MI, Yudintseva NM. Tissue engineering in urology, new approaches for urinary bladder reconstruction. Tsitologiya. 2015; 57(1): 14-18. (In Russian). 
2. Rohrmann D, Albrecht D, Hannappel J, Gerlach R, Schwarzkopp G, Lutzeyer W. Alloplastic replacement of the urinary bladder. J Urol. 1996; 156: 2094-2097.

3. Sloff, M. Simaioforidis V, de Vries R, Oosterwijk E, Feitz W. Tissue engineering of the bladder - reality or myth? A systematic review. J. Urol. 2014. 192(4): 1035-1042.

4. El Taji O, Khattak AQ, Hussain SA. Bladder reconstruction: The past, present and future (Review). Oncol Lett. 2015. 10(1): 3-10.

5. Zuban ON, Komjakov BK. Surgical correction of a minor urinary bladder. SPb:“Stiks”. 2011: 1-227 (In Russian).

6. Shao J, Chen C, Wang Y, Chen X, Du C. Early stage structural evolution of PLLA porous scaffolds in thermally induced phase separation process and the corresponding biodegradability and biological property. Polymer Degrad Stab. 2012; 97: 955-963.

7. Ho MH, Hou LT, Tu CY, Hsieh HJ, Lai JY, Chen WJ, Wang DM. Promotion of cell affinity of porous PLLA scaffolds by immobilization of RGD peptides via plasma treatment. Macromol Biosci. 2006; 6(1): 90-98.

8. Pattison MA, Wurster S, Webster TJ, Haberstroh KM. Three-dimensional, nano-structured PLGA scaffolds for bladder tissue replacement applications. Biomaterials. 2005; 26: 2491-2500.

9. Oberpenning F, Meng J, Yoo JJ, Atala A. De novo reconstitution of a functional mammalian urinary bladder by tissue engineering. Nat Biotechnol. 1999;17:149-155.

10. Atala A, Bauer SB, Soker S et al. Tissue-engineered autologous bladders for patients needing cystoplasty. Lancet. 2006; 367: 1241-1246.

11. Galkin VB, Mushkin AY, Muraviev AN, Serdobintsev MS, Belilovsky EM, Sinitsyn MV. The gender and age structure of the incidence of tuberculosis (various localizations) in the Russian Federation: changes over the XXI century Tuberculosis and Lung Diseases. 2018; 96(11):17-26. (In Russian).

12. Yudintceva NM, Bogolyubova IO, Muraviov AN, Sheykhov MG, Vinogradova TI, Sokolovich EG, Samusenko IA, Shevtsov MA. Application of the allogenic mesenchymal stem cells in the therapy of the bladder tuberculosis. Journal of Tissue Engineering Regener Med. 2018; 12(3): e1580-e1593.

13. Yudintceva NM, Nashchekina YA., Blinova MI, Orlova NV, Muraviov AN, Vinogradova TI, Sheykhov MG, Shapkova EY, Emeljannikov DV, Yablonskii PK, Samusenko IA, Mikhrina AL, Pakhomov AV, Shevtsov MA. Experimental bladder regeneration using a poly-l-lactide/silk fibroin scaffold seeded with nanoparticle-labeled allogenic bone marrow stromal cells. Int J Nanomedicine. 2016; 11:4521-4533.

14. Martínez-Montiel MP, Gómez-Gómez GJ, Flores AI. Therapy with stem cells in inflammatory bowel disease. World J Gastroenterol. 2014; 20(5): 1211-1127.

15. Onken J, Gallup D, Hanson J, Pandak M, Custer L. Successful outpatient treatment of refractory Crohn's disease us- ing adult mesenchymal stem cells. ACG 2006 Final Program Book. 2006: 121.

16. Liang J, Zhang H, Wang D, Feng X, Wang H, Hua B, Liu B, Sun L. Allogeneic mesenchymal stem cell transplantation in seven patients with refractory inflammatory bowel disease. Gut. 2012; 61: 468-469.

17. Du T, Zhu YJ. The regulation of inflammatory mediators in acute kidney injury via exogenous mesenchymal stem cells. Mediat Inflam. 2014. 2014: 261697. PMID: 24839354. DOI: $10.1155 / 2014 / 261697$.

18. Coutu DL, Mahfouz W, Loutochin O, Galipeau J, Corcos J. Tissue Engineering of Rat Bladder Using Marrow-Derived Mesenchymal Stem Cells and Bladder Acellular Matrix. PLoS One. 2014. 9(12): e111966. DOI: 10.1371.

19. Yuan H, Zhuang Y, Xiong J, Zhi W, Liu L, Wei Q, Han P. Human umbilical mesenchymal stem cells-seeded bladder acellular matrix grafts for reconstruction of bladder defects in a canine model. PLoS One. 2013. 8(11): e80959. PMID: 24278354. DOI: 10.1371/journal.pone.0080959.

20. Snow-Lisy DC, Diaz EC, Bury MI, Fuller NJ, Hannick $\mathrm{JH}$, Ahmad N, Sharma AK. The role of genetically modified mesenchymal stem cells in urinary bladder regeneration. PLoS One. 2015. 10(9): e0138643. PMID: 26398705. DOI: 10.1371/journal.pone. 


\title{
Экспериментальная реконструкция мочевого пузыря с использованием аллогенных тканеинженерных продуктов
}

\author{
Надежда В. Орлова ${ }^{1}$, Александр Н. Муравьев ${ }^{1,4}$, Татьяна И. Виноградова ${ }^{1}$, Наталья М. Юдинцева ${ }^{2}$, \\ Юлия А. Нащекина ${ }^{2}$, Наталья В. Заболотных ${ }^{1}$, Александр А. Лебедев ${ }^{1}$, Магомедсадык Г. Шейхов ${ }^{1}$, \\ Петр К. Яблонский ${ }^{1,3}$ \\ ${ }^{1}$ Санкт-Петербургский научно-исследовательский институт фтизиопульмонологии Минздрава России, \\ Санкт-Петербург, Россия \\ ${ }^{2}$ Институт цитологии РАН, Санкт-Петербург, Россия \\ ${ }^{3}$ Санкт-Петербургский государственный университет, Санкт-Петербург, Россия \\ ${ }^{4}$ Частное образовательное учреждение высшего образования «Санкт-Петербургский медико-социальный институт», \\ Санкт-Петербург, Россия
}

\section{Резюме}

В статье представлены результаты экспериментального исследования по частичной реконструкции мочевого пузыря кролика с использованием тканеинженерных конструкций на основе поли-L, L-лактида, содержащих в своем составе аллогенные клетки различного тканевого происхождения.

\section{Цель}

Экспериментальное изучение возможности применения аллогенного тканеинженерного трансплантата для замещения дефекта стенки мочевого пузыря.

\section{Материалы и методы}

15 кроликам-самцам породы «Шиншилла» выполнена парциальная резекция мочевого пузыря с имплантацией скаффолдов, содержащих гладкие миоциты с уротелием, фибробласты и мезенхимальные стволовые клетки, а также матрицей без клеток.

\section{Результаты}

В группе животных, получившей скаффолд с меченными мезенхимальными стволовыми клетками, в 5 случаях из 6 не зафиксировано признаков отторжения имплантата. Через 2,5 месяца после операции емкость мочевых пузырей была сравнима с дооперационной. В месте имплантации визуально определялся участок вновь сформированной стенки мочевого пузыря с признаками васкуляризации.
Гистологически выявлены начальные стадии репарации и ангиогенеза. При конфокальной микроскопии криосрезов в месте имплантации обнаружены меченые клетки, принимающие участие в формировании структуры, сходной с уротелием. Во всех случаях имплантации бесклеточной матрицей или скаффолдов, содержащих гладкие миоциты с уротелием и фибробласты, произошло отторжение имплантата с разной степени выраженности воспалительной реакцией и уменьшением емкости мочевого пузыря.

\section{Заключение}

Проведенный эксперимент подтверждает возможность использования мезенхимальных стволовых клеток в составе тканеинженерного продукта для частичного замещения стенки мочевого пузыря. Разработка методик создания многокомпонентного трансплантата с использованием аллогенных клеток может способствовать улучшению результатов лечения патологий, при которых получение аутологичного материала не представляется возможным.

\section{Ключевые слова}

Аллогенная трансплантация, мезенхимальные стромальные клетки костного мозга, мочевой пузырь, тканевая инженерия. 